Tokarski, A.K., Márton, E., Świerczewska, A., Fheed, A., Zasadni, J., Kukulak J. 2016: Neotectonic rotations in the Orava-Nowy Targ Intramontane Basin (Western Carpathians): an integrated palaeomagnetic and fractured clasts study. Tectonophysics 685, 35-43.

\title{
Neotectonic rotations in the Orava-Nowy Targ Intramontane Basin \\ (Western Carpathians): an integrated palaeomagnetic and fractured clasts study
}

Antek K. Tokarski ${ }^{\mathrm{a}}$, Emő Márton ${ }^{\mathrm{b}}$, Anna Świerczewska ${ }^{\mathrm{c}}$, Adam Fheed ${ }^{\mathrm{c}}$, Jurek Zasadni ${ }^{\mathrm{c}}$, Józek Kukulak $^{\mathrm{d}}$

${ }^{a}$ Polish Academy of Sciences, Institute of Geological Sciences, Research Centre in Cracow, Senacka 1, 31-002 Kraków, Poland

${ }^{\mathrm{b}}$ Geological and Geophysical Institute of Hungary, Palaeomagnetic Laboratory, Columbus utca 17-23, H-1145, Budapest, Hungary

c AGH University of Science and Technology, Faculty of Geology, Geophysics and Environmental Protection, Al. Mickiewicza 30, 30-059 Kraków, Poland

d Pedagogical University of Cracow, Institute of Geography, Podchorążych 2, 30-084 Kraków, Poland

The objectives of this contribution are: (1) to promote the application of fractured clasts analysis in conglomerates for regional stress reconstructions and (2) to advance reconstruction of the Western Carpathians structural development. Our results show that the Neogene fill of the Orava-Nowy Targ Intramontane Basin underwent $\mathrm{CCW}$ rotation of about $30^{\circ}$. We infer that the rotation terminated after $8 \mathrm{Ma}$ and was related to shift along NW-SE to NNW-SSE trending faults at the NE termination of the sinistral Mur-Žilina Fault Zone. Our results show that, fractured clasts analysis can be good tool for regional tectonic reconstructions. The tool is especially useful when other tectonic tools are scarce or absent. Results of our palaeomagnetic study and fractured clasts analysis verify and supplement each others. In the studied case, palaeomagnetic results allow to distinguish between regional stress field rotation and rotation of the Orava-Nowy Targ Basin Neogene fill, whereas, results of fractured clast analysis help to constrain the age of rotation. 
Keywords: Neotectonic rotations, Western Carpathians, Palaeomagnetism, Fractured clasts

\section{Introduction}

The first objective of this contribution is to promote the application of fractured clasts analysis in conglomerates for regional stress reconstructions. Since the pioneering studies of Kupsch (1955) and Ramsay $(1962,1964)$, fractured clasts in conglomerates and gravels have been widely studied. The results of these studies show that: (1) number of fractured clasts increases towards faults (Ramsay, 1964; Tyler, 1975; Tanner, 1976; Bradley and Bradley, 1986; Little, 1995), (2) clast-cutting fractures are largely joints oriented normal to the least compressive stress (Ramsay, 1964; Eildleman and Reches, 1992) and, (3) fractured clasts can be used as fault timing indicators (Tanner, 1976; Little, 1995; Dor et al., 2006) and can be useful for fault kinematic analysis (Ramsay, 1962, 1964; Bradley and Bradley, 1986). Instead of these assets, analysis of fractured clasts in conglomerates and gravels was included into regional stress reconstructions only exceptionally (e.g. Montes et al., 2005; Cuong et al., 2013). In this contribution, we present interpretation of clast-cutting fractures architecture in poorly indurated conglomerates within the Orava-Nowy Targ Basin (Fig. 1A, B). To validate this interpretation we compared these results with those of palaeomagnetic studies undertaken in claystones within the same basin.

We selected the Neogene sequence filling the Orava-Nowy Targ Basin as the study object for two reasons. First, the Neogene conglomerates bearing fractured clasts are well-exposed within the basin, whereas, the clasts-cutting fractures display well-organized architecture (Tokarski and Zuchiewicz, 1998; Kukulak, 1999). Second, palaeomagnetic studies of the Neogene sequence have been already initiated (Baumgart-Kotarba et al., 2004). The results of the latter suggest local moderate rotation of the Neogene strata around vertical axis. Other structural studies of the Orava-Nowy Targ Basin Neogene fill were hitherto restricted to single pilot analysis of small-scale faults (Pešková et al., 2009).

The second objective of this contribution is to advance reconstruction of the Western Carpathians structural development. The Orava-Nowy Targ Basin: (1) straddles across junction of the major tectonic units of the Western Carpathians (Fig. 1A) and, (2) is located close to the NE termination of the Mur-Žilina Fault Zone of prominent historical seismic activity (Lenhardt et al., 2007; Špaček et al., 2015) which was the NW boundary of the block 
shifted eastward due to lateral extrusion of the Eastern Alps (Ratschbacher et al., 1991). The Mur- Žilina Fault Zone is also called Vienna Basin Transform fault which was the locus of sinistral strike-slip movement during Neogene and Quaternary times (Decker et al., 2005). The activity of the Mur-Žilina Fault Zone has been essential for structural development of the Western Carpathians and Carpathian Foredeep during Neogene times (Fodor, 1995; Decker et al., 2005; Márton et al., 2011). It follows that the Orava-Nowy Targ Basin represents one of the key-areas for unraveling the Neogene tectonic evolution of the Western Carpathians.

\section{Geological setting}

The Western Carpathians are the northernmost segment of the European Alpides. To the North, they are thrusted over the Carpathian Foredeep filled by Neogene strata discordantly covering the southern margin of the European Platform (Fig. 1A). The Orava-Nowy Targ Basin straddles across (from the south to the north): the Inner Carpathians, the Pieniny Klippen Belt and the Outer Carpathians (Fig. 1B, C). The Inner Carpathians comprise a number of north-verging nappes formed during the Late Jurassic through Late Cretaceous times (Froitzheim et al., 2008 and references therein). Subsequently, the Inner Carpathians were covered by the Upper Cretaceous, Paleogene and Neogene strata, which are partially preserved in several intramontane basins. Within the study area, the Inner Carpathian nappes are covered by Paleogene strata of the intramontane Podhale Flysch Basin. The Pieniny Klippen Belt is a narrow zone of extreme shortening and wrenching formed since Late Cretaceous until Miocene times (Birkenmajer, 1986; Plašienka and Mikuš, 2010; Oszczypko and Oszczypko-Cloves, 2014). The Outer Carpathians are pile of north-verging nappes, the southernmost of which is Magura Nappe, formed since Eocene (Świerczewska and Tokarski, 1998) until Miocene (Cieszkowski et al., 1988; Oszczypko and Oszczypko-Cloves, 2014 and references therein; Kaczmarek and Oszczypko-Cloves, 2014) times. Subsequently, the Outer Carpathian nappe pile underwent regional collapse (Zuchiewicz et al., 2002 and references therein; Zattin et al., 2011 and references therein, Andreucci et al., 2013). During Miocene times Western Carpathians underwent general $\mathrm{CCW}$ rotation during two periods, between 18.5-17.5 and between 16.0 -14.5 Ma. The rocks older than 18.5 Ma show about $60^{\circ} \mathrm{CCW}$ rotation and those between 17.5 and 16.0 Ma old about $30^{\circ} \mathrm{CCW}$ rotation (Márton et al., 2009; Márton et al., 2015 and references therein). 
The Neogene fill of the Orava-Nowy Targ Basin is fairly well known owing to geological mapping and drillings supplemented by results of gravity and electric resistivity studies (for review see: Tokarski et al., 2012). The basin is filled by Neogene terrestrial and fresh water sequence, up to $1200 \mathrm{~m}$ thick (Fig. 2). The sequence is largely composed of poorly indurated claystones and siltstones with subordinate intercalations of poorly indurated conglomerates and sandstones.

The age of the sequence is very poorly constrained. Since middle 19 century (Halicki, 1930 and references therein) the sequence has been considered to be Neogene in age, based on comparison with similar strata filling the Vienna Basin. Results of subsequent palynological (e.g. Szafer, 1952; Zastawniak, 1972; Oszast, 1973; Tran, 1974; Oszast and Stuchlik, 1977; Worobiec, 1994; Birkenmajer and Worobiec, 2013) as well as faunistic (ostracods, bivalves and gastropods (Nagy et al., 1996 and references therein) studies and results of mineralogical analysis of a single bentonite intercalation (Sikora and Wieser, 1974) are interpreted as late Miocene or late Miocene to Pliocene age of the sequence. The youngest rocks underlying the Neogene sequence are the uppermost strata of the Magura Nappe, which are about $18 \mathrm{Ma}$ old (Kaczmarek and Oszczypko Clowes, 2014). This date constrain the lowest age of the sequence. The Orava-Nowy Targ Basin Neogene sequence is discordantly covered by Quaternary, mostly fluvial strata, composed largely of gravels (Watycha, 1973, 1977 c). A single fission track date of 8.7 +- 0.6 Ma was obtained by Ch. Naeser (in Worobiec, $1994 \mathrm{cf}$. Wieser, 1985) most likely on zircons from bentonite intercalation at locality (15). Unfortunately, no analytical data are provided.

The architecture of the Orava-Nowy Targ Basin is a subject of debate. According to results of geological mapping and drillings, the Neogene infill of the Orava-Nowy Targ Basin represents an open syncline (Fig. 1C), whereas, the results of geophysical studies (Pomianowski, 1995, 2003) imply that the basin is a composite graben. The strata in the central part of the basin dip sub-horizontally, whereas those close to the basin borders dip moderately towards the W-E trending basin axis.

\section{Material and methods}

\subsection{Palaeomagnetic sampling and laboratory processing}

We have collected 157 palaeomagnetic samples of Neogene strata from 10 localities (Fig.1B, Table 1, Appendix 1), taking special care to drill strata not affected by slumps. At 
localities 2, 11 and 15 sampling was repeated, since the exposure conditions improved after the first sampling campaign. The sampling was restricted to upper $700 \mathrm{~m}$ of the Neogene sequence (Fig. 2). The samples were drilled from poorly indurated fresh-looking, light to dark grey claystones with a portable drill in the field and oriented in situ with a magnetic compass. The sampled claystones were usually intercalated with mudstones, therefore, the orientations of bedding were measurable. Localities suspect for recent re-deposition were omitted from the sampling. The samples were packed in aluminium foil and stored refrigerated till they were cut into standard-size specimens in the laboratory (during cutting some of them disintegrated) and within a short time after cutting were subjected to standard paleomagnetic procedures of measuring and demagnetizations.

\subsection{Fractured clasts analysis}

Within the Orava-Nowy Targ Basin, Neogene conglomerates bearing fractured clasts occur in every visited exposure of the conglomerates. We studied architecture of clast-cutting fractures in the conglomerates at 8 localities (Fig. 1B, Appendix 1). The study was performed within upper $700 \mathrm{~m}$ of the Neogene sequence (Fig. 2). Moreover, at each locality the number of the fractured clasts per square meter was estimated. Additionally, at all localities clast lithology was studied, whereas, at some localities also clast shape, size and roundness were examined. At localities 9, 11, 14 and 15 share of matrix was calculated on photographs of exposures. Furthermore, geomorphological setting of most localities was studied on $1 \mathrm{~m}$ resolution digital elevation model (LiDAR DEM, source: www.codgik.gov.pl).

\section{Results}

\subsection{Palaeomagnetic results}

First, the natural remanent magnetization (NRM) was measured in the natural state. The intensity of the NRM was extremely variable between a few times $10^{-3}$ and $10^{-5} \mathrm{~A} / \mathrm{m}$, not only between localities, but often within one locality. At the same time the magnetic susceptibilities were always in the order of $10^{-4} \mathrm{SI}$, always less than $5 \times 10^{-4} \mathrm{SI}$. From each locality, a couple of specimens were first subjected to alternating field (AF) demagnetization, 
which invariably failed to yield acceptable demagnetization curves. In contrast, with stepwise thermal demagnetization, accompanied by monitoring of the magnetic susceptibility, well defined demagnetization curves were obtained for several localities (Fig.3). They document that the NRM is of single-component nature, it practically decays between 300 and $400^{\circ} \mathrm{C}$ while the susceptibility in this temperature interval is either stable or decreases. After $400^{\circ} \mathrm{C}$, the susceptibility increases dramatically (this part of the demagnetization behaviour is not shown in Fig. 3, since the NRM becomes unstable), indicating the decomposition of the original magnetic iron sulphide and the formation of magnetite on heating. The linear segments of the demagnetization curves for each locality were the input data for calculating the locality mean paleomagnetic directions in the geographic co-ordinate system.

The above obtained mean paleomagnetic directions were corrected for local tilts. The next step of processing the data was the calculation of overall-mean paleomagnetic directions from the locality mean directions of the seven localities yielding statistically well-defined results, both in geographic and tectonic co-ordinate systems (Table 1). The process was repeated for six localities with well-clustered directions (Table 1, Fig. 4), omitting sites 15a and b which are outliers. For both cases (seven or six localities considered), the scatter of the locality mean palaeomagnetic directions increases after tilt corrections, pointing to the post-tilting age of the acquisition of the NRM. Without locality 15, which indicates moderate $\mathrm{CW}$ rotation, the overall mean paleomagnetic direction shows $33^{\circ} \mathrm{CCW}$ rotation before and $25^{\circ} \mathrm{CCW}$ rotation after tilt corrections.

\subsection{Results of fractured clasts analysis}

The studied conglomerates are matrix-supported (Fig. 5). The share of silty to sandy matrix varies from 20 to $60 \%$ of the rock volume (cf. Kukulak, 1998; Fheed, 2014). The largerst clasts are over $100 \mathrm{~cm}$ in diameter (Fig. 5 A) (cf. Birkenmajer, 1979). Most clasts are discoidal or blade in shape (Fig. 5B, C). In most localities clasts are largely well rounded and rounded. Only in one locality (14) clasts are largely sub-angular. In most localities, clasts are composed almost exclusively of flysch sandstone or mudstone. Only in one locality(3) the share of non-flysch clasts (mostly limestones) amounts to $32 \%$ (Tokarski et al., 2012).

Clast-cutting fractures are restricted to particular clasts, the matrix of the conglomerates is not fractured (Fig. 5C, D). No striated clasts were observed. Moreover, very few fractures display fracture-parallel offset. The number of fractured clasts per square meter varies from 
10 (locality 13) to 126 (locality 11). At all studied localities the clast-cutting fractures are largely sub-vertical (Fig. 6) and the architecture of the fractures is well-organized. At seven localities (Fig. 6A-F), the fractures display two maxima (I, II), whereas, in the locality no. 13 the fractures show one elongated maximum (Fig. 6H). At particular localities, the angle between the maxima is $15-38^{\circ}$, whereas the mean value of the angle is $27^{\circ}$.

At four localities $(9,14-16)$, clast-cuttig fractures strike NNE-SSW to NNW-SSE (Fig. 6A D), whereas, at the remaining four localities $(3,11-13)$ the fractures strike ENE-SSW to E-W (Fig.6 E-H).

Numerous present-day landslides disturb outcrops of the Neogene sequence (Fig. 7) (cf. Watycha, 1977 c). Moreover, at some localities, conglomerates are cut by exposure-scale, non-planar fractures (Fig. 5 E, F) (cf. Kukulak, 1998). Some of these fractures are open and/or cut only the matrix of conglomerate, the clasts are not fractured.

\section{Discussion}

Within the Orava-Nowy Targ Neogene sequence the orientations of the palaeomagnetic vectors, which are of post-tilting age, are fairly consistent, suggesting CCW rotation (Table 1). Palaeomagnetic directions for the two sites of locality 15 can be explained by remagnetization post-dating the $\mathrm{CCW}$ rotation of the area.

In conglomerates, different fractures may arise depending on induration. In poorly indurated conglomerates (rigid clasts inbedded in viable matrix), fractures affect only clasts, whereas, when cementation is more advanced (matrix is also rigid), fractures cut both clasts and matrix or are restricted to the matrix (Hippolyte, 2001 and references therein, Cuong et al., 2013). As stated above, within the studied object clast-cutting fractures are restricted to particular clasts. It follows that clast-cutting fracturing took place early, preceding formation of the exposurescale fractures which cut only the matrix of conglomerates. Moreover, very few of the studied clast-cutting fractures display fracture-parallel offset and no striated fractures were observed. We infer, therefore, that large majority of the clast-cutting fractures are extensional joints (cf. Eildelman and Reches, 1992; Cuong et al., 2013). Most of the joints are sub-vertical and, in all but one (13) of the localities, they show two maxima, related to two sets of joints (I, II in Fig. 6). Joints of these sets result from two successive episodes of jointing which were separated either by $\mathrm{CW}$ rotation of the regional stress field or by $\mathrm{CCW}$ rotation of the Neogene sequence of the Orava-Nowy Targ Basin. A Neogene CW stress-field rotation of 
similar magnitude was already postulated for the Tatra Mts. (Fig. 1A) and its Paleogene cover by Pešková et al. (2009) and Králikowá et al. (2014 and references therein). Nevertheless, the mean value $\left(27^{\circ}\right)$ of the angle between the joints of particular sets (I, II) is very close to the mean angle value of the $\mathrm{CCW}$ rotation of the paleomagnetic vector $\left(33^{\circ}\right.$ before tilt correction, Table 1). It follows, that the Neogene sequence of the Orava-Nowy Targ Basin underwent $\mathrm{CCW}$ rotation and the two episodes of jointing took place in fixed regional stress setting, whereas, the joints of the set (I) were formed before the rotation, and those of the set (II) after the rotation.

Based on the orientation of the joints, two groups of exposures can be distinguished. In exposures of the first group (localities 9, 14-16; Fig. 6A-D) joints strike NNW-SSE to N-S (set I) and N-S to NNE-SSW (set II). In exposures of the second group (localities 3, 11-13; Fig. 6E-H) joints show strikes NNE-SSW to ENE-WSW (set I) and ENE-WSW to E-W (set II). It appears that, this variation of joints orientation can result from local, post-rotational reorientation of the Neogene conglomerates at exposures of the second group due to landsliding, or to local post-rotational variation within the regional stress field. The former possibility is our favored interpretation. In this interpretation, at all exposures joints of both sets were formed in a stress field in which minimum stress axis $\left(\sigma_{3}\right)$ was oriented E-W to ESE-WNW perpendicular to present-day orientation of the set II joints in the first group of exposures (localities 9, 14-16) and consistently with the stress field inferred for the OravaNowy Targ Neogene sequence during Pliocene times by Pešková et al. (2009).

The acquisition of the NRM is of post-tilting age, whereas, joints of both sets (I, II) occur within the Orava-Nowy Targ Neogene sequence including its uppermost part (Figs 2,6). It follows that the inferred landsliding took place after tilting of the Neogene strata as well as after formation of the second set of joints (II).

Moreover, it is highly feasible that the landsliding occurred during Quaternary times when the studied region underwent considerable uplift (Tokarski et al., 2012). The uplift resulted in formation of more prominent relief, which was low during the deposition of the Neogene sequence (Łoziński et al., 2015). The present-day landslides are widespread on outcrops of the Neogene strata within the study area (Fig. 7) (cf. Watycha, 1977 c,). The exposure-scale fractures cutting Neogene conglomerates at some of the studied exposures (Fig. 5E, F) can also result from recent slab sliding.

Joints of both discussed sets (I, II) were observed in both groups of exposures, also in the uppermost part of the Orava-Nowy Targ Basin Neogene sequence (Figs 2, 6). It follows that 
the $\mathrm{CCW}$ rotation took place after deposition of the sequence. Unfortunately, the age of the Neogene sequence is poorly constrained and, therefore, the age of the discussed rotation is hardly possible to precise. On the other hand, a $\mathrm{CCW}$ rotation of similar magnitude affected the Neogene sequence of the Carpathian Foredeep (Fig.1A) (Márton et al., 2011). The youngest strata affected by the last rotation is less than $8 \mathrm{Ma}$ old. Moreover, the CCW rotation of the Carpathian Foredeep Neogene sequence was related to dextral shift on the NW-SE trending faults of the Mur-Žilina Fault Zone. The Orava-Nowy Targ Basin is located close to the NE termination of this fault zone. So far only one NNW-SSE trending fault cutting the Neogene fill of the basin has been mapped (Fig. 1 B). Nevertheless, several NW-SE to NNWSSE trending faults cut the Magura Nappe immediately north from the basin (Fig.1 B). According to Struska (2009) most of these faults are dextral and, they can be traced on DEM models southward within the Neogene infill of the Orava-Nowy Targ Basin. Moreover, several dextral NW-SE trending faults cut the Neogene fill of the Carpathian Foredeep (Márton et al., 2011). We think, therefore, that the CCW rotation of the Orava-Nowy Targ Basin Neogene sequence was also related to the dextral shift along the NW-SE to NNW-SSE trending faults. In our interpretation these faults are connected to the Mur-Žilina Fault Zone (Fig. 8) that is regarded to be responsible for stress distortion in this part of the Carpathians (Jarosiński 1998, 2005). Reactivation of older basement faults as an agent of the rotation cannot be excluded. However, the uncoupled type of suture between the accretionary wedge and basement as well as weak stress transmission across this suture (Jarosiński 2005) suggest that an influence of the faults had limited impact on the rotation of the Neogene infill of the Orava-Nowy Targ Basin.

Summing up, it appears highly probable that the CCW rotation of the Orava-Nowy Targ Basin Neogene sequence was of the same age and origin and occurred by the same mechanism as the CCW rotation of the Carpathian Foredeep Neogene sequence. The MurŽilina Fault Zone was a locus of strike-slip movements since 17 Ma until 9-8 Ma, and again since the middle Pleistocene times (Decker et al., 2005). It follows that CCW rotation of the Orava-Nowy Targ Basin Neogene sequence took place either during late Neogene or during Quaternary. 


\section{Conclusions}

(1) Fractured clasts analysis can be good tool for regional tectonic reconstructions. The tool is especially important in cases when other tectonic tools are scarce or absent.

(2) Results of paleomagnetic studies and results of fractured clasts analysis verify and supplement each other. In the studied case, paleomagnetic results enable to distinguish between regional stress field rotation and rotation of the Neogene fill of the OravaNowy Targ Basin, whereas, results of fractured clast analysis help to constrain age of rotation.

(3) The Neogene sequence of the Orava-Nowy Targ Basin underwent CCW rotation of about $30^{\circ}$. In our interpretation, the rotation terminated after $8 \mathrm{Ma}$ and was related to dextral shift along NW-SE to NNW-SSE trending faults at the NE termination of the Mur-Žilina Fault Zone.

Acknowledgements. This research was funded by the award of grant from the Polish State budget funds for scientific research (research project 2012/07/B/ST10/04318) to Ania Świerczewska and by joint projects of the Academies of Sciences of Hungary and Poland as well as of Poland and Slovakia and by Hungarian Scientific Research Found OTKA project no. K 105245. Two constructive anonymous reviews considerably improved the quality of the paper.

\section{References}

Andreucci, B., Castellucio, A., Jankowski, L., Mazzoli, S., Szaniawski, R., Zattin, M., 2013. Burial and exhumation history of the Polish Outer Carpathians: Discriminating the role of thrusting and post-thrusting extension. Tectonophysics. 608, 866-883.

Baumgart-Kotarba, M., Marcak, H., Márton, E., 2004. Rotation along transverse transforming Orava strike-slip fault: Based on geomorphological, geophysical and paleomagnetic data (Western Carpathians). Geologica Carpathica. 55, 219-226.

Birkenmajer, K., 1979. Geological Guidebook of the Pieniny Klippen Belt. Wydawnictwa Geologiczne. Warszawa. 1-236. (in Polish).

Birkenmajer, K., 1986. Stages of structural evolution of the Pieniny Klippen Belt, Carpathians. Studia Geologica Polonica. 88, 7-32.

Birkenmajer, K., Worobiec, E., 2013. Pliocene fresh water pollen-bearing deposits in the Mizerna-Nowa bore hole, West Carpathians, Poland. Geolog ical Quarterly. 57, 73-88. 
Bradley, D.C., Bradley, L.M., 1986. Tectonic significance of the Carboniferous Big Pond Basin, Cape Breton Island, Nova Scotia. Canadian Journal of Earth Sciences. 23, 20002011.

Cieszkowski, M., Gonera, M., Oszczypko, N., Ślęzak, J., Zuchiewicz, W. 1988. Litostratigraphy and age of the upper Miocene deposits at Iwkowa, Polish West Carpathians. Bulletin of the Polish Academy of Sciences, Earth Sciences. 36, 309-329.

Cuong, N.Q., Tokarski, A.K., Świerczewska, A., Zuchiewicz, W.A., Yem, N.T., 2013. Late Tertiary tectonics of the Red River Fault Zone: Structural evolution of sedimentary rocks. Journal of Geodynamics. 69, 31-53.

Decker, K., Peresson, H., Hinsch, R., 2005. Active tectonics and Quaternary basin formation along the Vienna Basin Transform Fault. Quaternary Science Reviews. 44, 305-320.

Dor, O., Rockwell, T.K., Ben-Zion, Y., 2006. Geological observations of damage asymmetry in the structure of the San Jacinto, San Andreas and Punchbowl faults in Southern California: A possible indicator for preferred rupture propagation direction. Pure and Applied Geophysics. 163, 301-349.

Eildelman, A., Reches, Z., 1992. Fractured pebbles - a new stress indicator. Geology. 20, 307-310.

Fheed, A., 2014. The complex fault zone within poorly indurated strata in the Orava Basin (Western Carpathians, Poland). Geology, Geophysics \& Environment. 40, 82-83

Fisher, R.A., 1953. Dispersion on a sphere. Proceedings of the Royal Society London. 217, 295-305.

Fodor, L., 1995. From transpression to transtension: Oligocene-Miocene structural evolution of the Vienna Basin and the Eastern Alpine-Western Carpathian junction. Tectonophysics. 242, 151-182.

Froitzheim, N., Plašienka, D.,Schuster, R., 2008. Alpine tectonics of the Alps and Western Carpathians. In: McCann T. (Ed.): The Geology of Central Europe. 2. Mesozoic and Cenozoic. Geogical Society. London, 1141-1232.

Gross, P., Köhler, E., Mello, J., Haško, J., Halouzka, J., Nagy, A. et al. 1993. Geology of Southern and Eastern Orava. Geologický Ústav D. Śtúra. Bratislava. 1-319 (in Slovak, Englisch summary).

Halicki, R., 1930. La glaciations quaternaire du versant nord de la Tatra. Bulletin du Service Géologique de Pologne. 5, 505-534.

Hinsch, R., Decker K., 2011. Seismic slip rates, potential subsurface rupture areas and seismic potential of the Vienna Basin Transform Fault. International Journal of Earth Sciences. 100, 1925-1935.

Hippolyte, J.-C., 2001. Palaeostress and neotectonic analysis of sheared conglomerates: Southwest Alps and Southern Apennines. Journal of Structural Geology. 23, 421-429.

Jarosiński, M., 1998. Contemporary stress field distortion in the Polish part of the Western Outer Carpathians and their basement. Tectonophysics. 297: 91-119.

Jarosiński, M., 2005. Ongoing tectonic reactivation of the Outer Carpathians and its impact on the foreland: results of borehole breakout measurements in Poland. Tectonophysics. 410: 189-216. 
Kaczmarek, M., Oszczypko-Clowes, M., 2014. Marine Miocene deposits in the Orava-Nowy Targ Intramontane Basin (Magura Nappe - Polish Outer Carpathians). $9^{\text {th }}$ ESSEWECA Conference, Abstract Book, 24-25.

Kirschvink, J.L., 1980. The least-squares line and plane and the analysis of paleomagnetic data. Geophysical Journal of the Royal Astronomical Society. 62, 699-718.

Králiková, S., Vojtko, R., Sliva, L’, Minár, J., Fügenschuh., B., Kováč, M., Hók, J., 2014. Cretaceous - Quaternary tectonic evolution of the Tatra Mts (Western Carpathians): constraints from structural, sedimentary, geomorphological, and fission track data. Geologica Carpathica, 65, 307-326. doi: 10.2478/geoca-2014-0021.

Kukulak, J. 1998. Sedimentary characteristics of the topmost deposits, Domański Wierch alluvial cone (Neogene/Pleistocene), Orawa Depression, Polish Carpathians. Studia Geologica Polonica. 111, 93-111 (in Polish, English summary).

Kukulak, J., 1999. Orientation of joints and faults in the SE part of the Orawa Depression. Przegląd Geologiczny. 47, 1021-1026.

Kupsch, W.O., 1955. Drumlins with jointed boulders near Dollard, Saskatchewan. Geological Society of America Bulletin. 66, 327-338.

Lenhardt, W.A., Švancara, J., Melichar, P., Pazdírková, J., Haviř̆, J.,Sýkorová, Z., 2007, Seismic activity of the Alpine-Carpathian-Bohemian Massif region with regard to geological and potential field data. Geologica Carpathica. 58, 397- 412.

Lexa, J., Bezák, V., Elečko, M., Mello, J., Polák, M., Potfaj, M., Vozár, J. (Eds.), 2000. Geological map of Western Carpathians and adjacent areas 1: 500,000. Ministry of Environment of Slovak Republic, Geological Survey of Slovak Republic. Bratislava.

Little, T.A., 1995. Brittle deformation adjacent to the Awatere strike-slip fault in New Zealand: Faulting patterns, scaling relationships, and displacement partitioning. Geological Society of America Bulletin. 107, 1255-1271.

Łoziński, M., Wysocka, A., Ludwiniak, M. 2015. Neogene terrestrial sedimentary environments of the Orava-Nowy Targ basin: case study of the Oravica section near Čimhová, Slovakia. Geological Quarterly. 59, 21-34.

Márton, E., Rauch-Włodarska, M., Krejči, O., Tokarski, A.K., Bubik, M., 2009. An integrated palaeomagnetic and AMS study of the Tertiary flysch from the Outer Western Carpathians. Geophysics Journal International. 177, 925-940, doi: 10.1111/j.1365246X.2009.04104x

Márton, E., Tokarski, A.K, Krejčí, O., Rauch, M., Olszewska, B., Tomanová Petrová, P., Wójcik, A., 2011. "Non European" palaeomagnetic directions from the Carpathian Foredeep at the southern margin of the European plate. Terra Nova. 23, 134-144.

Márton, E., Grabowski, J., Tokarski, A.K. \& Túnyi, I., 2015. Palaeomagnetic results from the fold and thrust belt of the Western Carpathians: an overview. In: Pueyo, E. L., Cifelli, F., Sussman, A. J. \& Oliva-Urcia, B. (Eds): Palaeomagnetism in Fold and Thrust Belts: New Perspectives. Geological Society, London, Special Publications, 425, http://doi.org/10.1144/SP425.1.

Montes, C., Hatcher, R.D. Jr., Restrepo-Pace, A., 2005. Tectonic reconstruction of the northern Andean blocks: Oblique convergence and rotations derived from the kinematics of the Piedras-Girardot area, Colombia. Tectonophysics. 399, 221-250. 
Nagy, A., Vass, D., Petrík, F., Pereszlényi, M., 1996: Tectonogenesis of the Orava Depression in the light of latest biostratigraphic investigations and organic matter alteration study. Slovak Geological Magazine. 1, 49-58.

Oszast, J., 1973. The Pliocene profile of Domański Wierch near CzarnyDunajec in the light of palynological investigations, Western Carpathians, Poland. Acta Palaeobotanica. 14, 142.

Oszast, J., Stuchlik, L., 1977. The Neogene Vegetation of the Podhale (West Carpathians, Poland). Acta Palaebotonica. 18, 45-86.

Oszczypko, N., Oszczypko-Clowes, M., 2014. Geological structure and evolution of the Pieniny Klippen Belt to the east from the Dunajec River - a new aproach (Western Carpathians, Poland). Geological Quarterly. 58, 737-758. DOI: http://dx.doi.org/10.7306/gq.1177

Pešková, I., Vojtko R., Starek D., Sliva L'., 2009. Late Eocene to Quaternary deformation and stress field evolution of the Orava region (Western Carpathians). Acta Geologica Polonica. 59, 73-91.

Plašienka, D., Mikuš, V., 2010. Geological settings of the Pieniny and Šariš sectors of the Klippen Belt between Litmanová and Drienica villages in eastern Slovakia. Mineralia Slovaca. 42, 155-178.

Pomianowski, P., 1995. Structure of the Orava Basin in the light of selected geophysical data. Annales Societatis Geologorum Poloniae. 64, 67- 80. (in Polish, English summary).

Pomianowski, P., 2003. Tectonics of the Orava-Nowy Targ Basin - results of the combined analysis of the gravity and geoelectrical data. Przegląd Geologiczny. 51, 498-506. (in Polish, English summary).

Ramsay, D.M., 1962., The Highland Boundary Fault: reverse or wrench fault? Nature. 195, 1190-1191.

Ramsay, D.M., 1964. Deformation of pebbles in the lower Old Red Sandstone conglomerates adjacent to the Highland Boundary Fault. Geological Magazine. 101, 228-248.

Ratschbacher, L., Frisch, W., Linzer, H.- G., Merle, O., 1991. Lateral Extrusion in the Eastern Alps, Part 2: Structural Analysis. Tectonics, 10. 257-271.

Sikora, W., Wieser, T., 1974. Piroclastics within Neogene strata of the Orava-Nowy Targ Basin. Geological Quarterly. 18, 441-443. (in Polish).

Špaček, P., Bábek, O., Štěpančiková, P., Švancara, J., Pazdírková, J., Sedláček, J., 2015. The Nysa-Morava Zone: an active tectonic domain with Late Cenozoic sedimentary grabens in the Western Carpathians' foreland (NE Bohemian Massif). International Journal of Earth Sciences. 104, 963-990. DOI 10.1007/s00531-014-1121-7.

Struska, M., 2009. Tectonics of the Orava Basin. LXXIX Assembly of the Polish Geological Society, Conference Materials, 76-80. (in Polish).

Szafer, W., 1952. The young Tertiary of the Podhale and its relation with the Pleistocene. Bulletin of Geological Institute. 56, 555-556. (in Polish).

Świerczewska, A., Tokarski, A.K., 1998. Deformation bands and the history of folding in the Magura nappe, Western Outer Carpathians (Poland). Tectonophysics. 297, 73-90.

Tanner W.F., 1976. Tectonically significant pebble types: Sheared, pocked and second-cycle examples. Sedimentary Geology. 16, 69-83. 
Tokarski, A.K., Zuchiewicz, W., 1998. Fractured clasts in the Domański Wierch series: Contribution to structural evolution of the Orava Basin (Carpathians, Poland) during Neogene through Quaternary times. Przegląd Geologiczny. 46, 62-6.

Tokarski, A.K., Świerczewska, A., Zuchiewicz, W., Starek, D., Fodor L., 2012. Quaternary exhumation of the Carpathians: a record from the Orava-Nowy Targ Intramontane Basin, Western Carpathians (Poland and Slovakia). Geologica Carpathica. 63, 257-266. doi: 10.2478/v10096-012-0021-7

Tran, D.N., 1974. Palynological investigations of Neogene deposits in the Nowy Targ -Orawa Basin (West Carpathians, Poland). Acta Palaeobotanica. 15, 1-81.

Tyler, J. H., 1975. Fracture and rotation of brittle clasts in a ductile matrix. Journal of Geology. 83, 501-10.

Watycha, L., 1973. Quaternary formations in borehole Wróblówka, Podhale region. Geological Quarterly. 17, 335-345. (in Polish).

Watycha, L. 1977a. Explanations to the Detailed Geological Map of Poland 1: 50,000. Sheet Jabłonka (1047). Polish Geological Institute. Warsaw. 1-72 (in Polish).

Watycha, L., 1977b. Detailed Geological Map of Poland 1: 50,000. Sheet Jabłonka (1047). Polish Geological Institute. Warsaw. (in Polish).

Watycha, L., 1977c. Detailed Geological Map of Poland 1: 50,000. Sheet Czarny Dunajec (1048). Polish Geological Institute. Warsaw. (in Polish).

Worobiec, G., 1994. Upper Miocene fossil plants from the outcrop of Stare Bystre (Western Carpathians, Poland). Acta Palaeobotanica. 34, 83-105.

Wieser, T., 1985. The Teschenite formation and other evidences of magmatic activity in the Polish Flysch Carpathians. Carpaho-Balkan Geological Association 13 Congress, Fundamental Researches in the Western Part of the Polish Carpathians, Guide to excursion 1, 26-36.

Zastawniak, E., 1972. Pliocene leaf flora from Domański Wierch near Czarny Dunajec, Western Carpathians, Poland. Acta Palaeobotanica. 13, 1-73.

Zattin, M., Andreucci, B., Jankowski, L., Mazzoli, S., Szaniawski R., 2011. Neogene exhumation in the Outer Western Carpathians. Terra Nova. 23, 283-291.

Zuchiewicz, W., Tokarski, A.K., Jarosiński, M., Márton, E., 2002. Late Miocene to present day structural development of the Polish segment of the Outer Carpathians. Stephan Mueller Special Publication Series. 3, 185-202. 


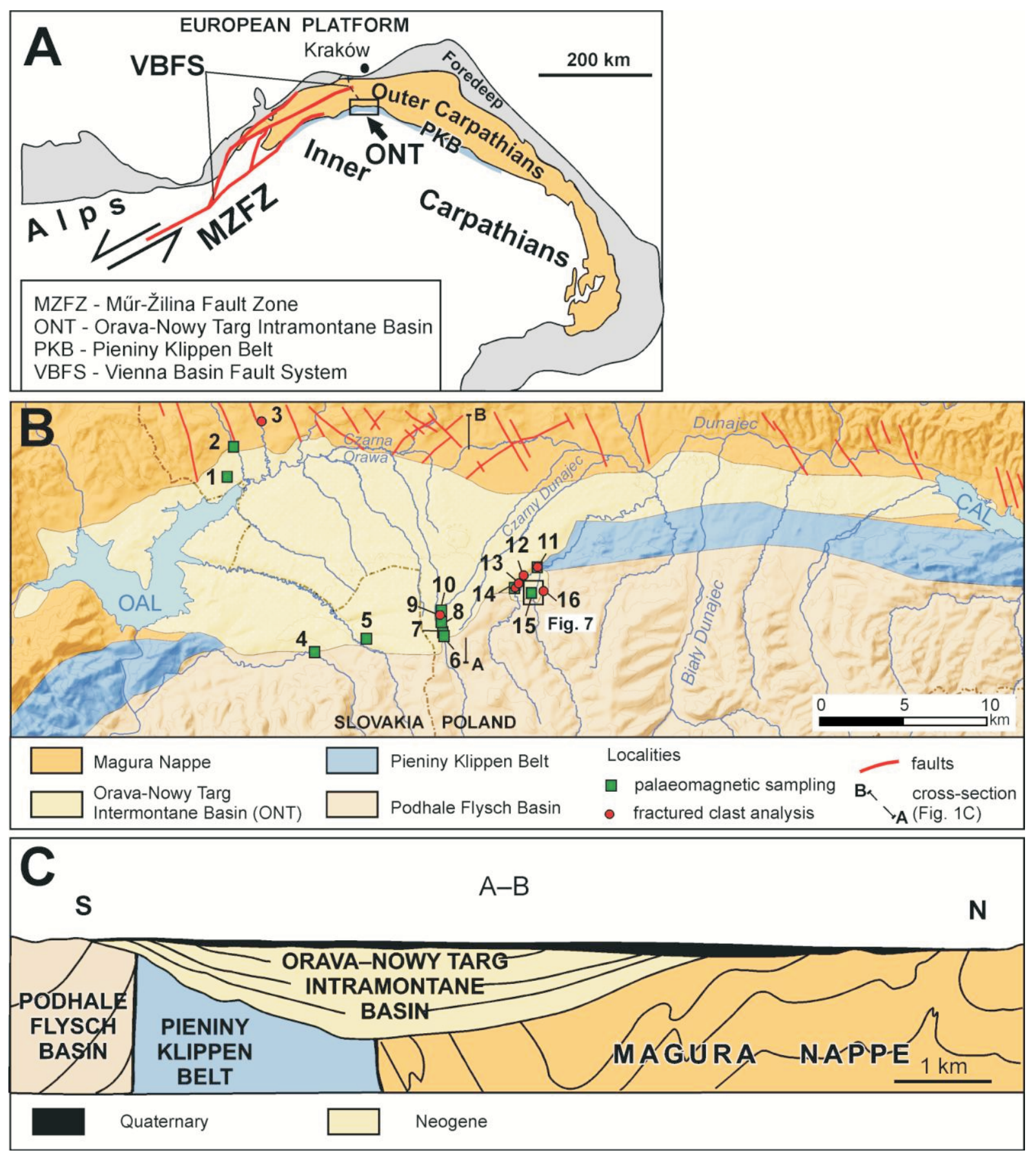

Fig. 1.

(A) Position of the Orava-Nowy Targ Intramontane Basin (ONT) within the Carpathian-Alpine orogenic system; active setting of the Mur- Žilina Fault Zone (Vienna Basin Transfer Fault) after Decker et al. (2005) and, Hinsch and Decker (2011). (B) Geological sketch-map of the ONT showing location of studied localities, location of Fig. 7 boxed, fault cutting the ONT Neogene fill marked by arrow, OAL - Orava artificial lake, CAL - Czorsztyn artificial lake, geology after Watycha (1977a), Lexa et al. (2000, simplified) and Pomianowski (2003). (C) Geological cross-section of the ONT (adapted from Watycha (1977b), for location see Fig. 1 B 


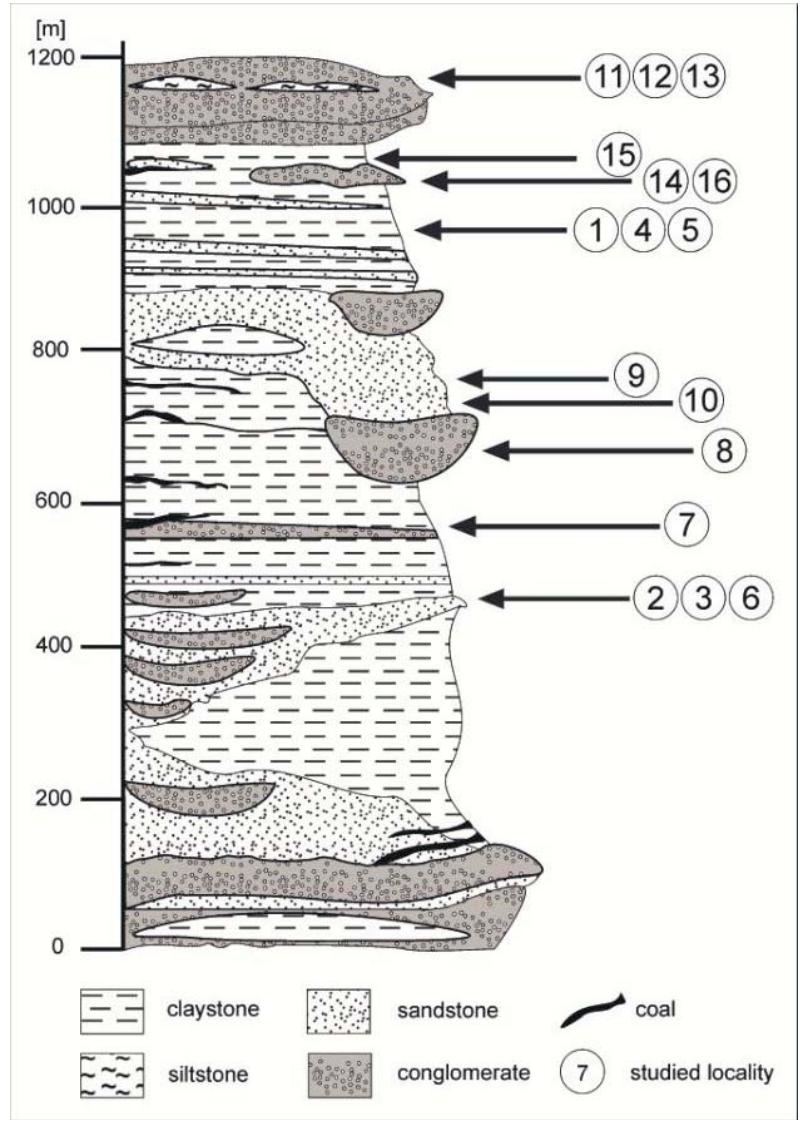

Fig. 2

Litostratigraphical column of the Orava-Nowy Targ Intramontane Basin Neogene sequence showing location of studied localities, litostratigraphy after Watycha (1977 c) and Gross et al. (1993) 

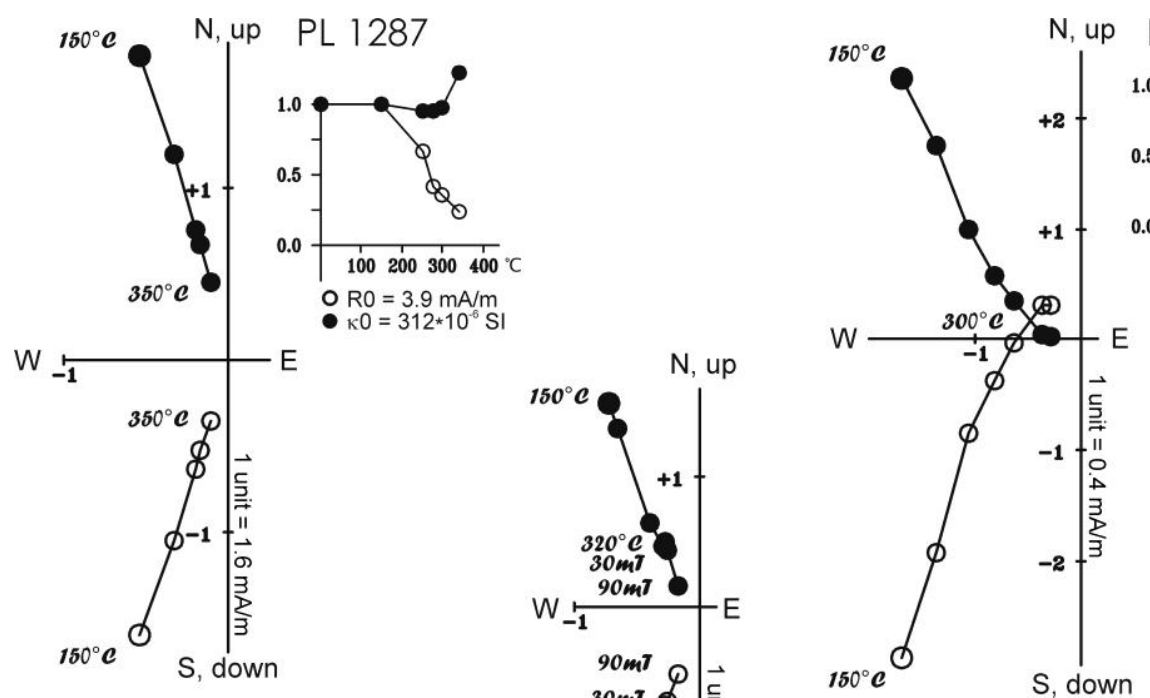

PL 1373A
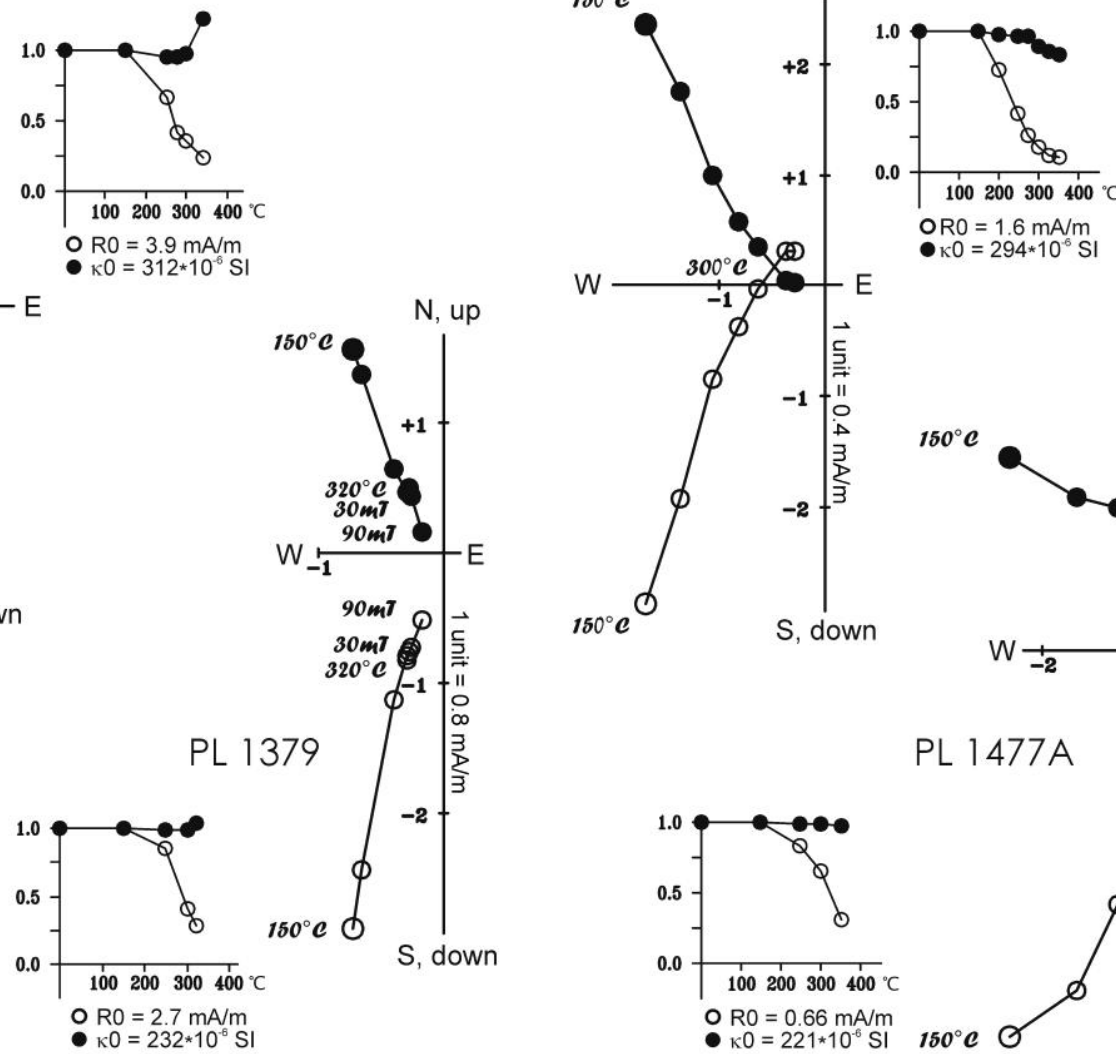

S, down

$150^{\circ} \mathrm{C}$

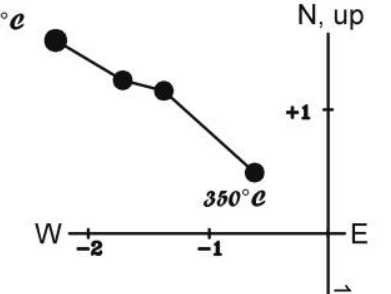

PL 1477A
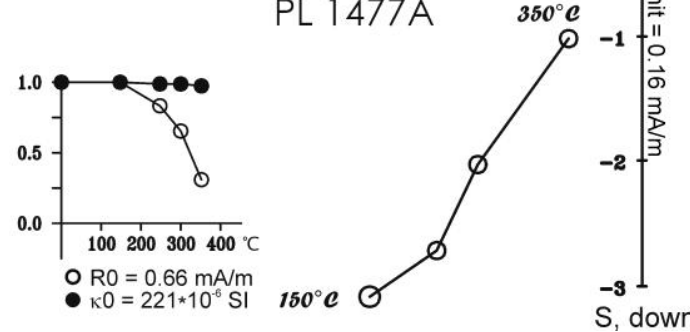

Fig. 3.

Typical demagnetization curves. In all cases, thermal demagnetization was efficient, since the carrier of the NRM must be magnetic iron sulphide. NRM practically decays before the magnetic susceptibility starts to increase, indicating the phase transition of the original magnetic mineral to magnetite. Key to Zijderveld diagrams: full dots: projection of the NRM vector onto the horizontal, circles: into the vertical. Geographical system. Zijderveld diagrams are accompanied by intensity (circles) and susceptibility (dots) versus temperature diagrams 


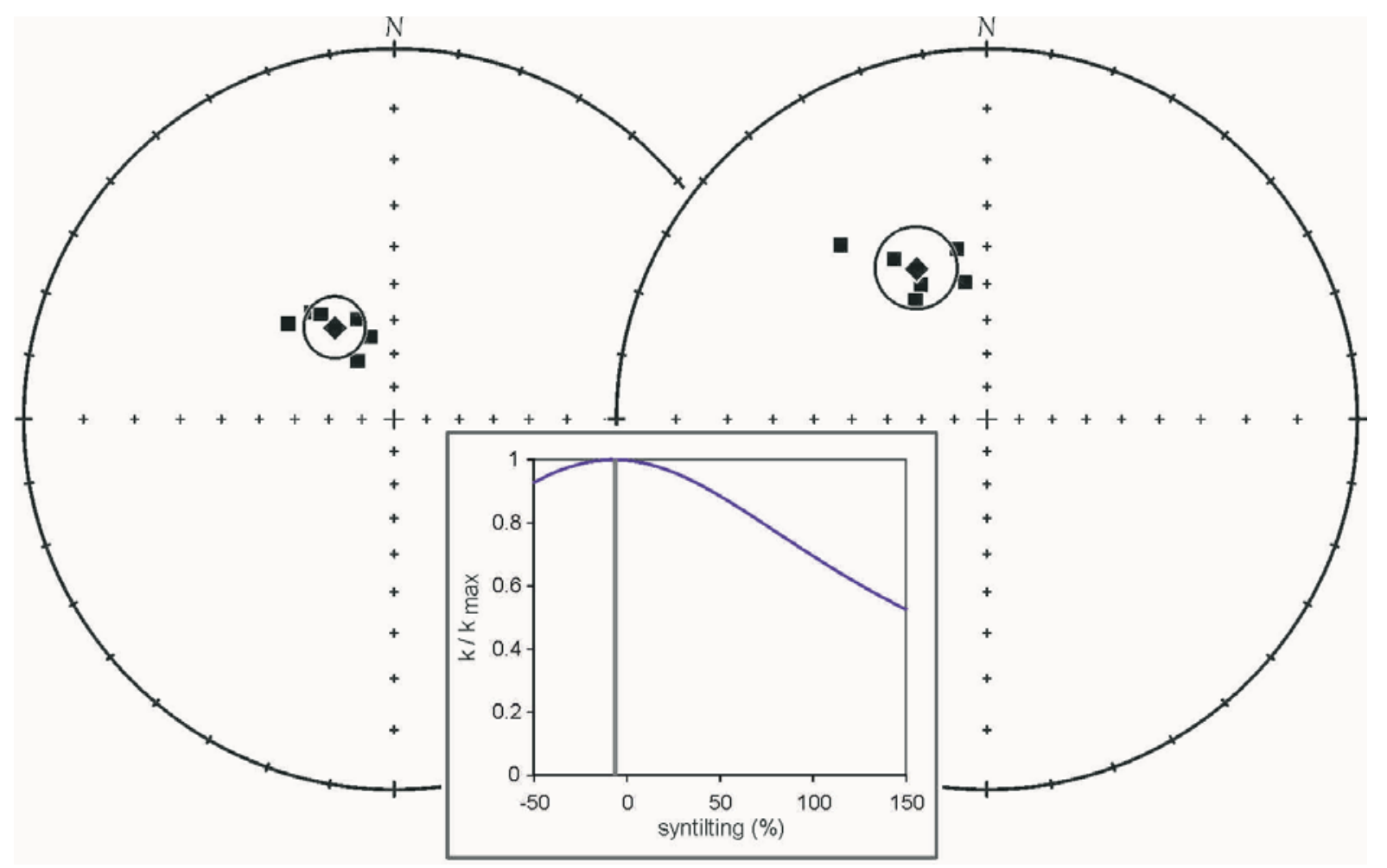

Fig. 4.

Tilt test carried out for six localities showing well-clustered locality mean directions before tilt corrections. Note that the best grouping is achieved in the present position of the strata (zero untilting) 

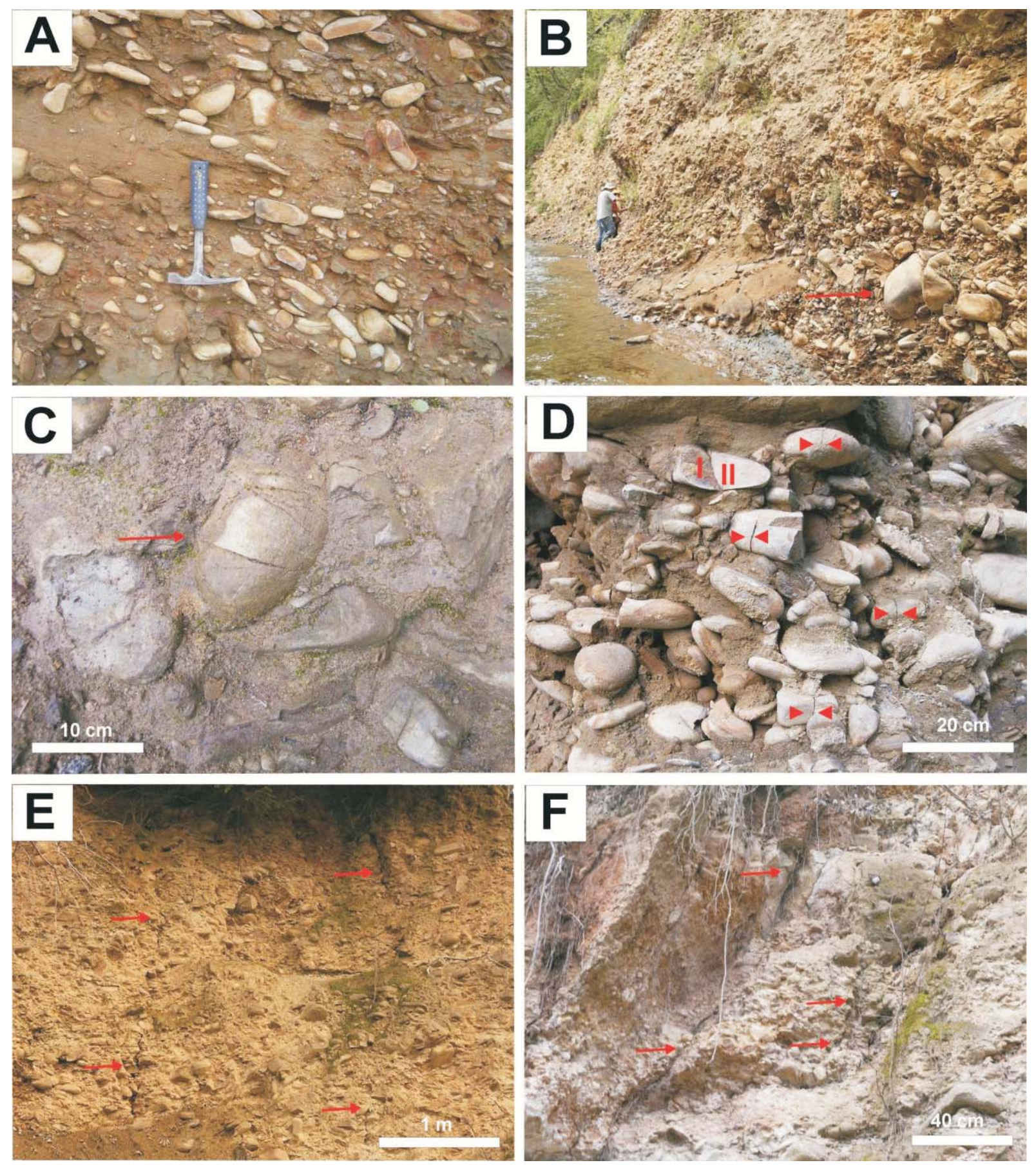

\section{Fig. 5}

Neogene matrix-supported conglomerates. A- arrowed clast is $80 \mathrm{~cm}$ in diameter (locality 11). B- most clasts are discoidal or blade in shape (locality 11 ). C- numerous fractured clasts (arrowed), long arrow shows clast cut by joints of two sets (I, II) (locality 11). D- fractures are restricted to particular clasts (arrowed) (locality 11). E, F- exposure-scale recent fractures (locality 15) 

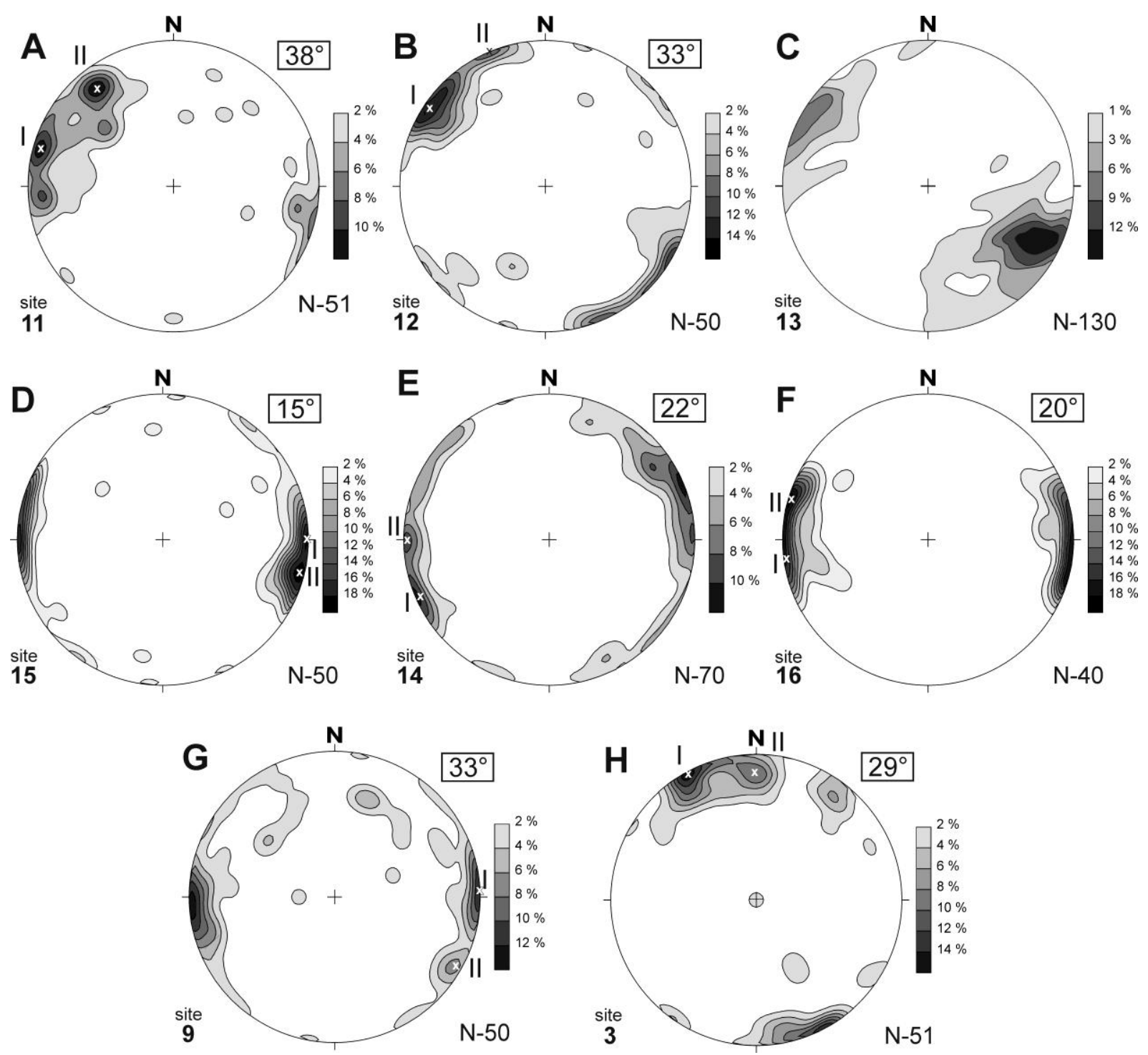

Fig. 6.

Clast-cutting joints, lower hemisphere plots, number in the left lower plot corner denotes locality number, whereas, that at the right lower plot corner the number of measurements and that at the right upper plot corner the value of angle between joints of the sets I and II; I, II - joint maxima discussed in text 


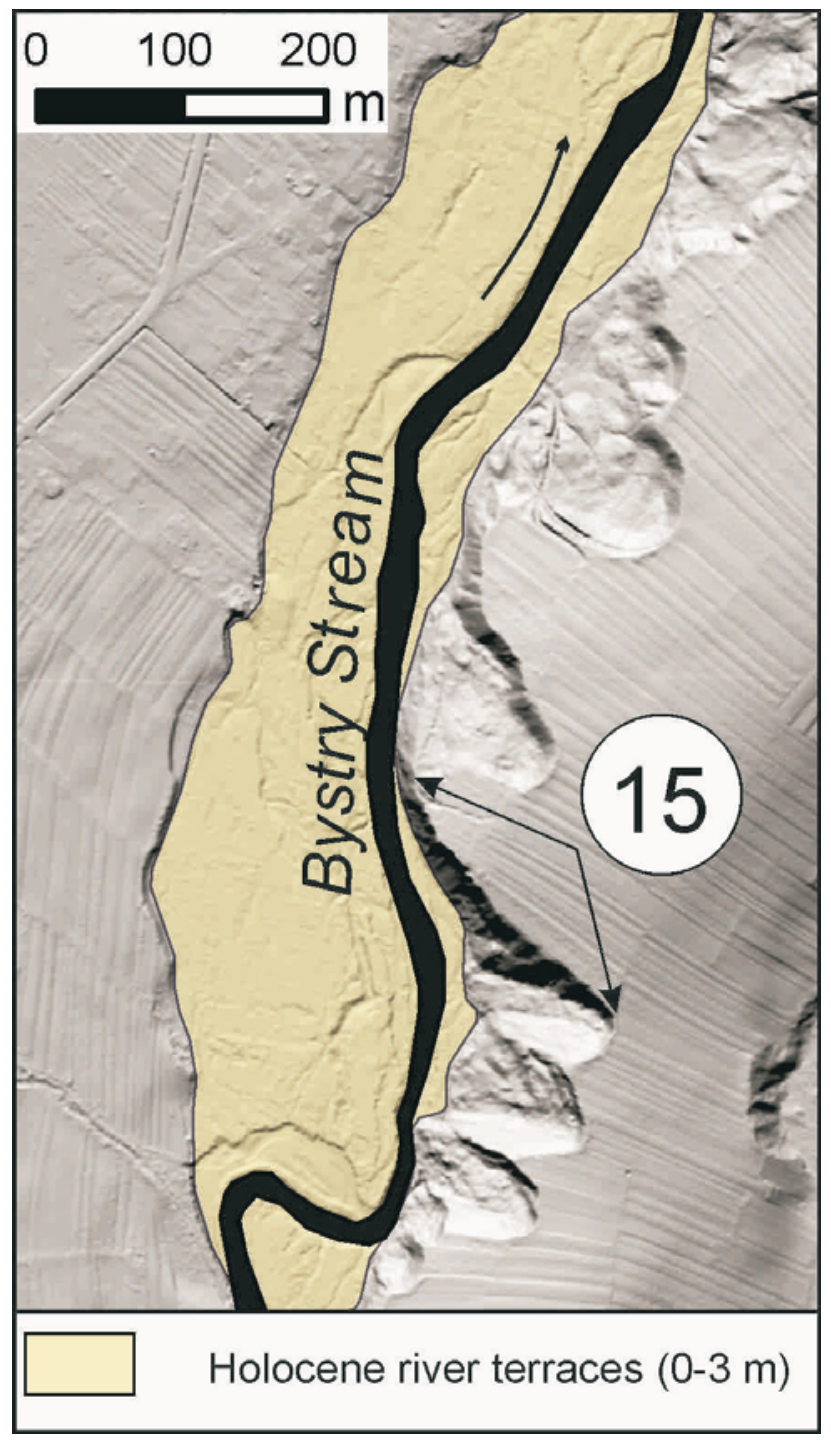

Fig. 7

Landslides at the right bank of Bystry Stream, position of locality 15 arrowed. One meter resolution digital elevation model (LiDAR DEM). For location see Fig. 1 


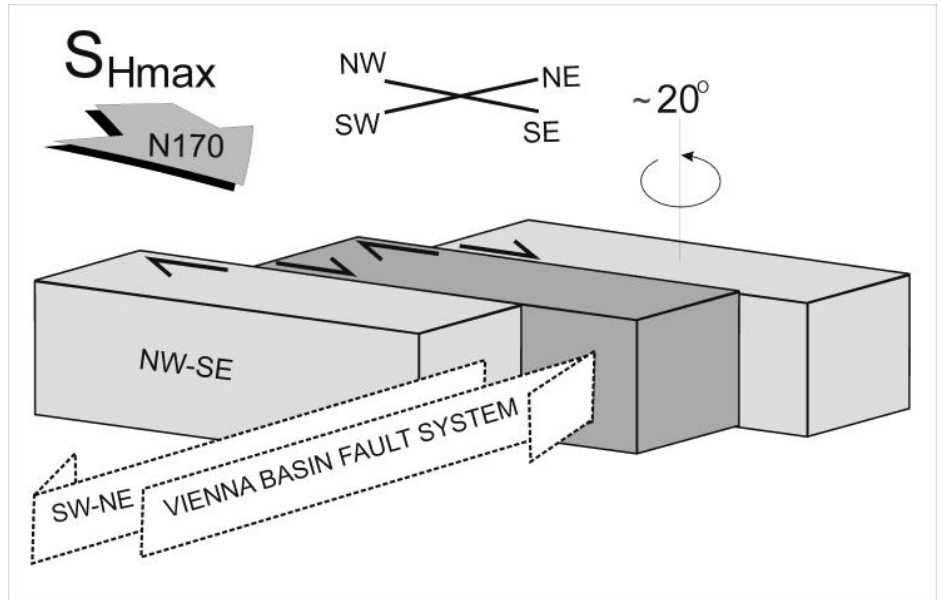

Fig. 8

Geometric model illustrating simultaneous dextral shift on NW-SE trending strike-slip faults and CCW rotation of fault-bounded blocks in the Orava-Nowy Targ Intramontane Basin, dextral slip and CCW rotation can be accommodated by contemporaneous left-lateral shear along the SW-NE trending Mur-Žilina Fault Zone related to eastward extrusion in the Eastern Alps (adapted from Márton et al., 2011) 
Table 1.

Summary of locality mean palaeomagnetic directions for Orawa-Nowy Targ Intramontane Basin, based on the results of principal component analysis (Kirschvink, 1980). Localities are numbered according to Fig. 1. Key: $n /$ no: number of used/collected samples (the samples are independently oriented cores); D, I (Dc, Ic): declination, inclination before (after) tilt correction; $k$ and a95: statistical parameters (Fisher, 1953)

\begin{tabular}{|c|c|c|c|c|c|c|c|c|c|c|c|c|}
\hline Locality & Site & $\begin{array}{l}n / n o \\
N(n)\end{array}$ & $\mathbf{D}^{\circ}$ & $1^{\circ}$ & $\mathbf{k}$ & $a_{95}^{\circ}$ & $\mathrm{D}_{\mathrm{c}}{ }^{\circ}$ & $\mathrm{I}_{\mathrm{C}}{ }^{\circ}$ & $\mathbf{k}$ & $a_{95^{\circ}}$ & dip & Remark \\
\hline $\begin{array}{c}1 \\
\text { Lipnica Wielkafield } \\
95 / 1\end{array}$ & $\begin{array}{c}1 \\
\text { PL } 619631\end{array}$ & $8 / 13$ & 344 & +64 & 42 & 9 & 351 & +49 & 42 & 9 & $\begin{array}{l}\text { 4/16 from } \\
\text { AMS }\end{array}$ & $\begin{array}{c}\text { only } \\
\text { foliation }\end{array}$ \\
\hline \multirow{2}{*}{$\begin{array}{c}\mathbf{2} \\
\text { Lipnica Wielkariver } \\
09 / 10\end{array}$} & $\begin{array}{c}\text { 2a } \\
\text { PL 600-608 }\end{array}$ & $0 / 9$ & \multicolumn{8}{|c|}{ large scatter } & $\begin{array}{c}135 / 9 \\
\text { from AMS }\end{array}$ & $\begin{array}{l}\text { lineation } \\
160 / 8\end{array}$ \\
\hline & \begin{tabular}{|c|}
$\mathbf{2 b}$ \\
PL 1357-1371
\end{tabular} & $5 / 15$ & \multicolumn{8}{|c|}{ great circle distribution from 5 samples } & $180 / 15$ & $\begin{array}{c}\text { lineation } \\
337 / 8\end{array}$ \\
\hline $\begin{array}{c}4 \\
\text { Čimhová } \\
10 / 15\end{array}$ & $\begin{array}{c}\mathbf{4} \\
\text { PL 14681486 }\end{array}$ & $8 / 19$ & 312 & +48 & 21 & 12 & 320 & +27 & 21 & 12 & $344 / 24$ & $\begin{array}{c}\text { lineation } \\
103 / 2\end{array}$ \\
\hline $\begin{array}{c}\mathbf{5} \\
\text { Hladowka } \\
95 / 3\end{array}$ & $\begin{array}{c}\mathbf{5} \\
\text { PL 632-638 }\end{array}$ & $6 / 7$ & 148 & -69 & 17 & 17 & 149 & -49 & 17 & 17 & $330 / 20$ & \\
\hline $\begin{array}{c}\mathbf{6} \\
\text { Chochołów } 3 \\
09 / 11\end{array}$ & $\begin{array}{c}\mathbf{6} \\
\text { PL 13721377 }\end{array}$ & $5 / 6$ & 322 & +50 & 43 & 12 & 330 & +37 & 43 & 12 & $0 / 15$ & $\begin{array}{l}\text { scattered } \\
\text { AMS }\end{array}$ \\
\hline $\begin{array}{c}7 \\
\text { Chochołów } 1 \\
08 / 21\end{array}$ & $\begin{array}{c}7 \\
\text { PL 12701286 }\end{array}$ & $0 / 17$ & \multicolumn{8}{|c|}{ large scatter } & $340 / 20$ & $\begin{array}{l}\text { scattered } \\
\text { AMS }\end{array}$ \\
\hline $\begin{array}{c}8 \\
\text { Chochołów } 2 \\
08 / 22\end{array}$ & $\begin{array}{c}\mathbf{8} \\
\text { PL 1287-1295 }\end{array}$ & $9 / 9$ & 340 & +58 & 27 & 10 & 350 & +40 & 27 & 10 & $10 / 20$ & $\begin{array}{l}\text { lineation } \\
225 / 5\end{array}$ \\
\hline $\begin{array}{c}10 \\
\text { Koniówka } \\
09 / 12\end{array}$ & $\begin{array}{c}\mathbf{1 0} \\
\text { PL 13781383 }\end{array}$ & $4 / 6$ & 325 & +52 & 29 & 17 & 334 & +46 & 29 & 17 & $20 / 10$ & $\begin{array}{c}\text { lineation } \\
271 / 3\end{array}$ \\
\hline \multirow{2}{*}{$\begin{array}{c}11 \\
\text { Stare Bystre } \\
95 / 2\end{array}$} & $\begin{array}{c}11 \mathrm{a} \\
\text { PL 642-652 }\end{array}$ & $0 / 11$ & \multicolumn{8}{|c|}{ large scatter } & $150 / 15$ & \\
\hline & $\begin{array}{c}\mathbf{1 1 b} \\
\text { PL 12961307 }\end{array}$ & $0 / 12$ & \multicolumn{8}{|c|}{ large scatter } & $150 / 15$ & $\begin{array}{c}\text { lineation } \\
294 / 19\end{array}$ \\
\hline \multirow{3}{*}{$\begin{array}{c}15 \\
\text { Miętustwo } 1 \\
95 / 5\end{array}$} & $\begin{array}{c}\text { 15a } \\
\text { PL 609-618 }\end{array}$ & $8 / 10$ & 28 & +78 & 69 & 7 & 29 & +53 & 69 & 7 & $28 / 25$ & $\begin{array}{c}\text { lineation } \\
282 / 14\end{array}$ \\
\hline & \begin{tabular}{c|} 
15b \\
PL 1621-1629
\end{tabular} & $9 / 9$ & 1 & +57 & 169 & 4 & 0 & +47 & 169 & 4 & $355 / 10$ & $\begin{array}{c}\text { only } \\
\text { foliation }\end{array}$ \\
\hline & $\begin{array}{c}\text { 15c } \\
\text { PL 16301643 }\end{array}$ & $10 / 14$ & \multicolumn{8}{|c|}{ great circle distribution from 10 samples } & $355 / 10$ & $\begin{array}{l}\text { scattered } \\
\text { AMS }\end{array}$ \\
\hline \multicolumn{2}{|c|}{$\begin{array}{c}\text { overall mean direction } \\
\text { all localities }\end{array}$} & $7 / 7$ & 330 & +61 & 32 & 11 & 341 & +45 & 20 & 14 & & \\
\hline \multicolumn{2}{|c|}{$\begin{array}{r}\text { overall mean direction } \\
\text { w/o locality } 15\end{array}$} & $6 / 7$ & 327 & +57 & 59 & 9 & 335 & +42 & 41 & 11 & & \\
\hline
\end{tabular}


Appendix 1 Location of studied localities

\begin{tabular}{|c|c|c|c|}
\hline Locality & $\begin{array}{l}\text { Type of } \\
\text { study }\end{array}$ & Latitude $\mathrm{N}$ & Longitude $\mathrm{E}$ \\
\hline 1 - Lipnica Wielka field (95.1) & $\mathrm{P}$ & $49^{\circ} 28.016^{\prime}$ & $19^{\circ} 37.808^{\prime}$ \\
\hline 2 - Lipnica Wielka Stream (09.10) & $P$ & $49^{\circ} 28.550^{\prime}$ & $19^{\circ} 38.062^{\prime}$ \\
\hline 3 - Sylec Stream (95.4) & $\mathrm{F}$ & $49^{\circ} 29.388^{\prime}$ & $19^{\circ} 39.398^{\prime}$ \\
\hline 4 - Cimhova (10.15) & $P$ & $49^{\circ} 21.971^{\prime}$ & $19^{\circ} 42.231^{\prime}$ \\
\hline 5 - Hladovka (95.3) & $P$ & $49^{\circ} 22.54^{\prime}$ & $19^{\circ} 44.554^{\prime}$ \\
\hline 6 - Chochołów 3 (09.11) & $P$ & $49^{\circ} 22.527^{\prime}$ & $19^{\circ} 48.679^{\prime}$ \\
\hline 7 - Chochołów 1 (08.21) & $\mathrm{P}$ & $49^{\circ} 22.628^{\prime}$ & $19^{\circ} 48.648^{\prime}$ \\
\hline 8 - Chochołów 2 (08.22) & $P$ & $49^{\circ} 22.983^{\prime}$ & $19^{\circ} 48.555^{\prime}$ \\
\hline 9 - Czarny Dunajec River (06.4) & $\mathrm{F}$ & $49^{\circ} 23.193^{\prime}$ & $19^{\circ} 48.494^{\prime}$ \\
\hline 10 - Koniówka (09.12) & $\mathrm{P}$ & $49^{\circ} 23.321^{\prime}$ & $19^{\circ} 48.548^{\prime}$ \\
\hline 11 - Stare Bystre (95.2) & $\mathrm{F}, \mathrm{P}$ & $49^{\circ} 24.801^{\prime}$ & $19^{\circ} 53.307^{\prime}$ \\
\hline 12 - Cichy Stream 1 (14.30) & $\mathrm{F}$ & $49^{\circ} 24.513^{\prime}$ & $19^{\circ} 52.625^{\prime}$ \\
\hline 13 - Cichy Stream 2 (14.32) & $\mathrm{F}$ & $49^{\circ} 24.263^{\prime}$ & $19^{\circ} 52.419^{\prime}$ \\
\hline 14 - Mietustwo 2 (05.5) & $\mathrm{F}$ & $49^{\circ} 24.136^{\prime}$ & $19^{\circ} 52.180^{\prime}$ \\
\hline 15 - Miętustwo 1 (95.5) & $\mathrm{F}, \mathrm{P}$ & $49^{\circ} 23.969^{\prime}$ & $19^{\circ} 53.011^{\prime}$ \\
\hline 16 - Czerwony Stream (14.50) & $\mathrm{F}$ & $49^{\circ} 24.025^{\prime}$ & $19^{\circ} 53.631^{\prime}$ \\
\hline
\end{tabular}

$\mathrm{P}$ - palaeomagnetic sampling; $\mathrm{F}$ - fractured clast analysis 